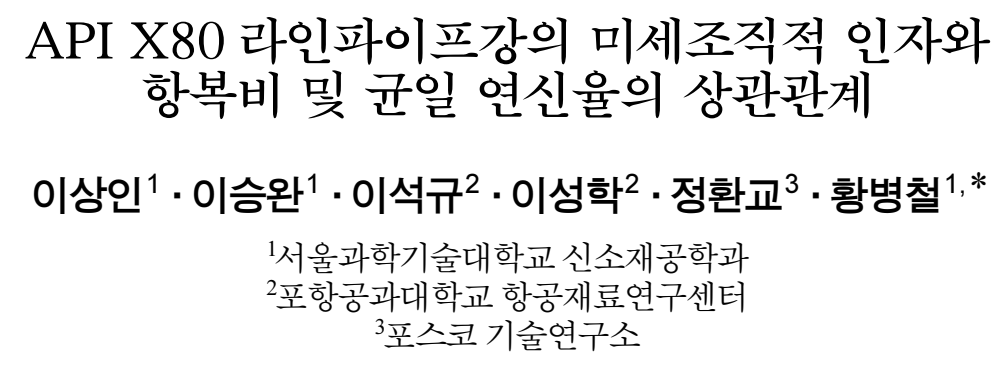

\title{
Correlation of Microstructural Factors with the Yield Ratio and Uniform Elongation in API X80 Linepipe Steels
}

\author{
Sang-In Lee ${ }^{1}$, Seung-Wan Lee ${ }^{1}$, Seok Gyu Lee ${ }^{2}$, Sunghak Lee ${ }^{2}$, Hwan Gyo Jung ${ }^{3}$, and Byoungchul Hwang, * \\ ${ }^{1}$ Department of Materials Science and Engineering, Seoul National University of Science and Technology, \\ Seoul 01811, Republic of Korea \\ ${ }^{2}$ Center for Advanced Aerospace Materials, Pohang University of Science and Technology, Pohang 37673, Republic of Korea \\ ${ }^{3}$ Technical Research Laboratories, POSCO, Pohang 37859, Republic of Korea
}

\begin{abstract}
In the present study, the correlation of microstructural factors with yield ratio and uniform elongation was investigated in API X80 linepipe steels with different microstructures by varying thermomechanical control process conditions. The grain size and microstructure fraction of the API X80 linepipe steels were quantitatively measured by EBSD analysis and then tensile tests were carried out on them. Although all the steels showed complex microstructures of polygonal ferrite ( $\mathrm{PF}$ ), and bainitic microstructures such as acicular ferrite (AF), granular bainite (GB), and bainitic ferrite (BF), they had different grain sizes and microstructure fractions. The $\mathrm{D}$ steel with the finest grain size showed the highest yield strength due to grain refinement strengthening even though it had a relatively high fraction of $\mathrm{PF}$ with lower yield strength. The yield ratio usually increases with decreasing grain size because grain refinement typically produces an increase in yield strength and a decrease in work hardening due to the accumulation of dislocations at grain boundaries. On the other hand, uniform elongation increases with increasing PF fraction because an increase in the PF fraction eases slip and thus reduces plastic instability caused by accumulated dislocations at grain boundaries. Consequently, the microstructural factors affecting the yield ratio, uniform elongation, and work hardening exponent of the API X80 linepipe steels are different, and the work hardening exponent is considered to be a parameter affected by stress and strain simultaneously. Therefore, it was confirmed that there is no general correlation between yield ratios, uniform elongations, and work hardening exponents in the API X80 linepipe steels investigated in this study, and previously reported API linepipe steels.
\end{abstract}

(Received February 22, 2018 ; Accepted April 9, 2018)

Keywords: linepipe steels, yield ratio, uniform elongation, grain size, microstructure fraction, work hardening exponent

\section{1. 서 론}

라인파이프 강재는 설계 시 파이프 내 가스나 오일에

*Corresponding Author: Byoungchul Hwang

[Tel: +82-2-970-6638, E-mail: bhwang@seoultech.ac.kr]

Copyright (C) The Korean Institute of Metals and Materials
의한 내압(hoop stress)만을 고려한 응력기초설계(stressbased design)가 일반적이다 [1-6]. 그러나 가스나 원유의 채굴 환경이 갈수록 열악해 짐에 따라 지진이나 동토 지 역에서 파이프라인의 건설 시 지반의 움직임에 대하여 변 형능(deformability)이 높은 강재가 요구되면서 파이프 길 이 또는 수직 방향으로의 변형능이 우수한 변형기초설계 
(strain-based design)가 강재에 적용되고 있다 [7-22]. 일 반적으로 파이프의 변형능을 평가하는 기준으로 압축 좌 굴변형률(compression buckling strain)이 주로 사용되는 데[23-28], 좌굴변형률은 강관의 변형 시 좌굴이 발생하 기 전까지의 변형률을 말하며, 강재의 균일 연신율, 가공 경화지수, 연속 항복 거동, 항복비 등에 의존한다 [1517]. 즉, 압축 좌굴변형률은 강재가 불연속 항복 거동을 가질 경우 감소하며, 가공 경화 지수가 클수록 증가한다 [27,28]. 또한 항복비 증가에 따라 대체로 감소하며 파이 프의 내압이 작용할 경우 증가하는 것으로 알려져 있다 [25,27].

한편 최근 심해 $2000 \mathrm{~m}$ 이상에서 채취된 가스나 원유를 수송시키기 위한 심해저용 강재가 개발되고 있는데, 이를 적용한 파이프의 경우 설치/운영시 해저에서의 안정성 및 외부 압력을 고려해야 한다 [29-33]. 특히 파이프를 설계할 때 외부 압력에 의한 좌굴변형 저항성, 복합 설치응력에 의한 국부 좌굴 저항성 및 외부 덴트(dent)에 의한 국부 좌굴 저항성을 고려해야 한다 $[29,30]$. 따라서 외부압력과 굽힘이 작용하는 심해저용 파이프 강재의 안정성을 확보하 기 위해 저항복비 특성이 요구되고 있는데, 항복비가 낮을 수록 국부 좌굴과 굽힘시 변형능력이 증가하고, 허용 결함 크기 및 파열(burst) 발생 임계 응력이 증가한다 [30]. 낮 은 항복비는 변형경화능을 높이고, 균열선단에서의 소성변 형을 감소시켜 유동응력과 관련된 연성파괴 저항성을 증가 시키는 것으로 알려져 있다 [21,33]. 이러한 심해저용 저항 복비 보증 미국석유협회(American Petroleum Institute, $\mathrm{API}) \mathrm{API} X 70$ 급 라인파이프 강재의 경우 항복비 $90 \%$ 이 하를 만족하는 강재가 이미 개발되었으며, 최근 $85 \%$ 이하 까지 보증이 가능한 강종 개발이 활발히 진행 중이다.

그러나 국내외적으로 개발 및 생산되고 있는 고강도 API 라인파이프 강재들의 경우 매우 복잡한 형태의 베이 나이트 조직(bainitic microstructure)으로 이루어져 있으며 연구자들마다 서로 다른 미세조직 정의와 구분법을 적용 하고 있어 항복비, 균일 연신율 및 가공경화지수 등과 같 은 인장 특성에 미치는 미세조직적 인자의 영향에 대한 정 확한 이해가 크게 미흡한 실정이다. 따라서 본 연구에서는 다양한 미세조직 구성상을 가지는 6 종류의 API X80급 라인파이프 강재에 대하여 미세조직을 광학현미경 및 전자 후방산란회절(electron backscatter diffraction, EBSD)을 이용하여 분석한 후, 인장 시험을 실시하여 항복비 및 균 일 연신율에 미치는 미세조직적 인자의 영향에 대해 고찰 하였다.

\section{2. 실험 방법}

본 연구에서 사용된 API X80 라인파이프 강재는 $\mathrm{Fe}-$ $0.06 \mathrm{C}-0.31 \mathrm{Si}-1.58 \mathrm{Mn}-0.50(\mathrm{Ni}+\mathrm{Cu}+\mathrm{Cr})-0.04 \mathrm{Nb}-0.015 \mathrm{Ti}$ 의 동 일한 화학 조성을 가지며, 열간 압연 이후 냉각 종료 온도 (finish cooling temperature), 냉각 단계 및 냉각 속도 (cooling rate) 등의 가공열처리공정(thermo-mechanical control process, TMCP) 조건에 따라 $20 \mathrm{~mm}$ 두께를 갖는 6 종류의 API 라인파이프 강재를 제조하였다. 제조된 API 라인파이프 강재들의 미세조직은 압연 판재의 옆면 (longitudinal-short transverse plane, L-S plane)을 연마하고 $3 \%$ 나이탈 용액으로 에칭한 후 광학현미경으로 관찰하였다. 또한 본 연구에서 제조된 API 라인파이프 강재의 경우 비 재결정 영역(non-recrystallization region)에서의 큰 압하량과 가속 냉각(accelerated cooling) 때문에 복잡한 형태의 베이 나이트 조직이 형성되어 이를 구분하고 정량적으로 미세조 직 분율을 측정하기 위해 $\mathrm{EBSD}$ 분석을 실시하였다. EBSD 시편은 압연 판재의 두께 $1 / 4$ 되는 위치의 L-S면을 기계적 으로 연마한 후 $92 \%$ 아세트산과와 $8 \%$ 과염소산을 혼합하 여 넣은 분사식 전해연마기로 전해연마를 실시하여 기계적 연마로 인해 발생된 표면의 결함을 제거하였다. EBSD 분석 은 전계방출형 주사전자현미경(field emission scanning electron microscope, FE-SEM) 내에서 분석하였으며, 결정 방위는 TSL사(Tex SEM Laboratories Inc.)에서 제공하는 배향 영상 현미경(orientation imaging microscopy, OIM) 분석 소프트웨어를 이용하였다.

인장 시편은 미국재료시험협회(American Society for Testing and Materials, ASTM) 규격인 ASTM E8에 따 라 제조된 API 라인파이프 강재의 두께 $1 / 4$ 되는 위치에 서 압연 방향(rolling direction)의 수직 방향(transverse direction)으로 표점 거리 $25 \mathrm{~mm}$, 직경 $6.3 \mathrm{~mm}$ 의 sub-size 봉상 시편으로 가공하고, 10 톤 용량의 만능인장시험기를 사용하여 $5 \mathrm{~mm} / \mathrm{min}$ 의 크로스 헤드(cross-head) 속도로 상 온에서 인장 시험하였다. API 5L 규정[34]에 따라 항복 강도(yield strength)는 응력-변형률 곡선으로부터 $0.5 \%$ 변 형률에 해당하는 유동 응력(flow stress)으로 정의하였으며, 인장 강도(tensile strength), 항복비(yield ratio), 균일 연신 율(uniform elongation), 총 연신율(total elongation) 및 가공경화지수(work hardening exponent)를 측정하였다.

\section{3. 실험 결과}

\section{1 미세조직}



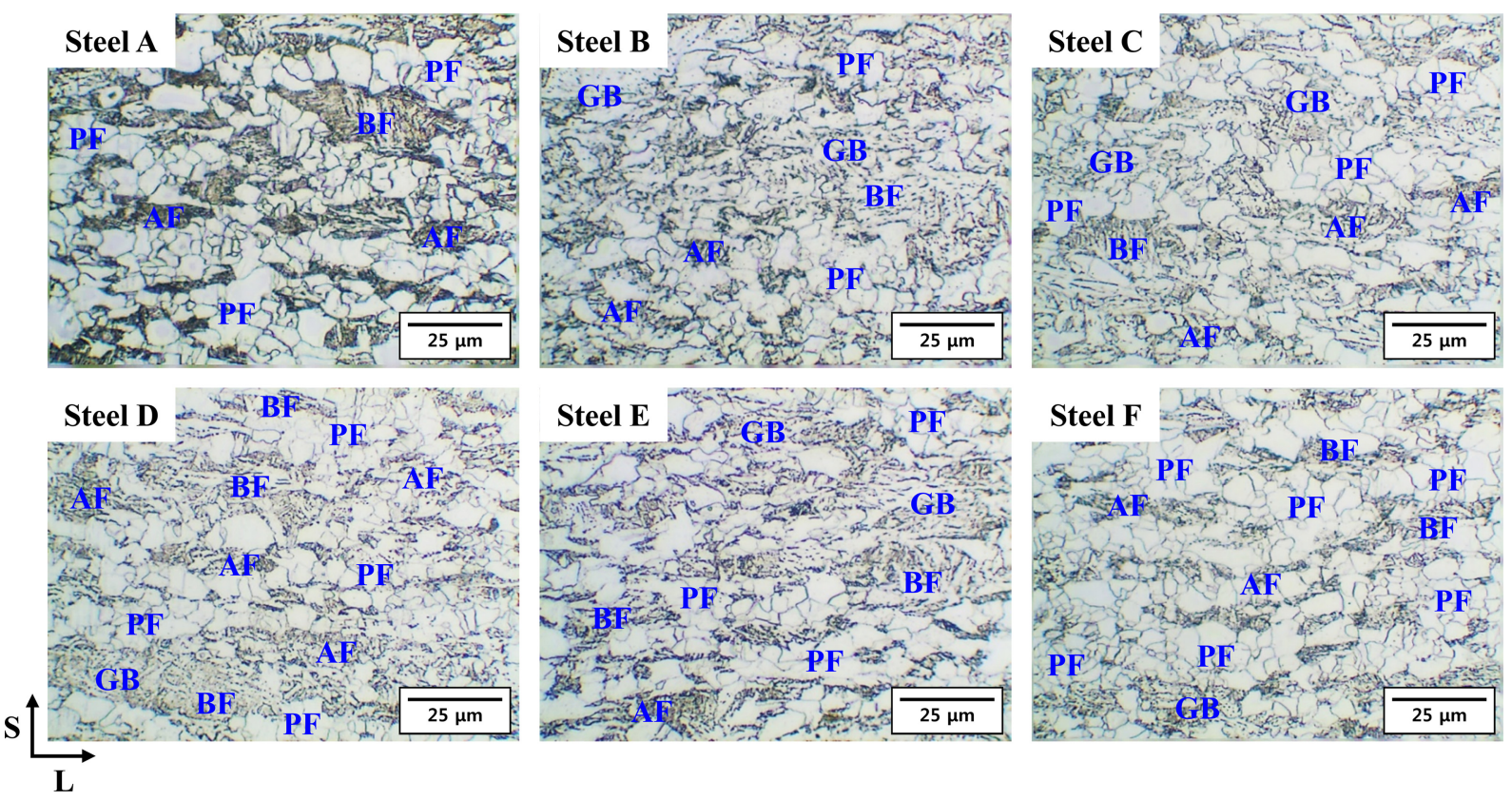

Fig. 1. Optical micrographs of the API X80 linepipe steels investigated in this study.

최근 저탄소와 $\mathrm{TMCP}$ 공정에 의해 제조되는 $\mathrm{API}$ 라인 파이프 강재에서는 다각형 페라이트(polygonal ferrite, $\mathrm{PF}$ ) 와 침상 페라이트(acicular ferrite, $\mathrm{AF})$, 과립형 베이나이트 (granular bainite, GB) 및 베이나이트형 페라이트(bainitic ferrite, $\mathrm{BF}$ ) 등의 베이나이트 조직들이 혼합된 매우 복잡한 미세조직이 나타나며, 합금 원소 및 제조 공정 조건에 따 라 각 미세조직의 분율이 달라진다. 그러나 이들 베이나이 트 조직들의 경우 거시적으로나 실험적으로 구분하기 매우 어렵고, 연구자들마다 다르게 정의하고 있어 본 연구에서 는 제조된 API 라인파이프강 강재의 미세조직을 $\mathrm{PF}$ 와 베 이나이트 조직으로 구분하였다.

본 연구에서 동일한 화학 조성을 갖고 다양한 제조 공정 에 따라 제조된 6종류의 API 라인파이프강 강재의 미세조 직을 광학현미경으로 관찰하여 그림 1 에 나타냈다. 모든 강재에서 $\mathrm{PF}$ 와 베이나이트 조직이 혼합되어 존재함을 관 찰할 수 있다. 특히 $\mathrm{PF}$ 의 경우 완전 재결정으로 인해 결 정립 내부에 낮은 전위 밀도의 특징을 가지기 때문에 그림 1 에서 뚜렷하게 구분됨을 알 수 있다. 하지만 어둡게 보이 는 베이나이트 조직의 경우 문헌[35-40]에서 보고되고 있 는 $\mathrm{AF}, \mathrm{GB}$ 및 $\mathrm{BF}$ 의 상을 구분하는 것이 한계가 있음을 확인할 수 있다.

한편 본 연구에서 제조된 API 강재의 미세조직을 보다 정확하게 구분하고, 미세조직적 인자를 정량적으로 분석 하기 위해 $\mathrm{EBSD}$ 분석을 실시하여, 그 결과를 그림 2 와
3에 나타냈다. 모든 강재에서 $\mathrm{PF}$ 와 베이나이트 조직으로 구성된 미세조직이 뚜렷하게 나타났는데, 특히 결정립계 및 커널 평균 방위차(kernel average misorientation, $\mathrm{KAM}$ ) 그림을 보면 $\mathrm{PF}$ 의 경우 모든 결정립계가 고경각 계(high-angle grain boundary)로 이루어져 있고 결정립 내부에 전위 밀도가 매우 낮은 특징을 알 수 있다(그림 2). 베이나이트 조직은 상대적으로 조대한 결정립 특징 을 보이고 있으며 결정립 내부에 저경각계(low-angle grain boundary)가 다수 존재함을 확인할 수 있다. 이 는 베이나이트 조직의 일반적인 특징으로 $\mathrm{AF}, \mathrm{GB}$ 및 $\mathrm{BF}$ 의 경우 불완전한 재결정, 빠른 냉각속도에 의한 상 변태로 인해 결정립 내부에 상대적으로 전위 밀도가 높 기 때문이다.

본 연구에서 $\mathrm{PF}$ 의 분율은 $\mathrm{OIM}$ 분석 소프트웨어를 이 용한 결정립 방위차 스프레드(grain orientation spread, $\mathrm{GOS}$ ) 그림을 활용하였다. GOS 분석은 하나의 결정립 안에서 각 점(point) 간의 평균 방위차(misorientation)를 계산하여 조건에 부합하는 결정립을 $\mathrm{PF}$ 로 결정하는 방법 으로 이전 연구 결과[40]를 토대로 하여 $\mathrm{PF}$ 와 베이나이 트 조직을 구분하기 위해 $5^{\circ}$ 의 결정립과 $2^{\circ}$ 의 방위차 조 건을 사용하여 $\mathrm{PF}$ 의 분율을 정량적으로 측정하였다. 또한 저배율 $\mathrm{EBSD}$ 분석을 통해 $15^{\circ}$ 의 결정립 조건에서 결정 립 크기를 측정하였으며, 그 결과를 표 1에 나타냈다. 먼 저 결정립 크기 분석 결과를 보면, $\mathrm{D}$ 강은 $6.7 \mu \mathrm{m}$ 로 가 


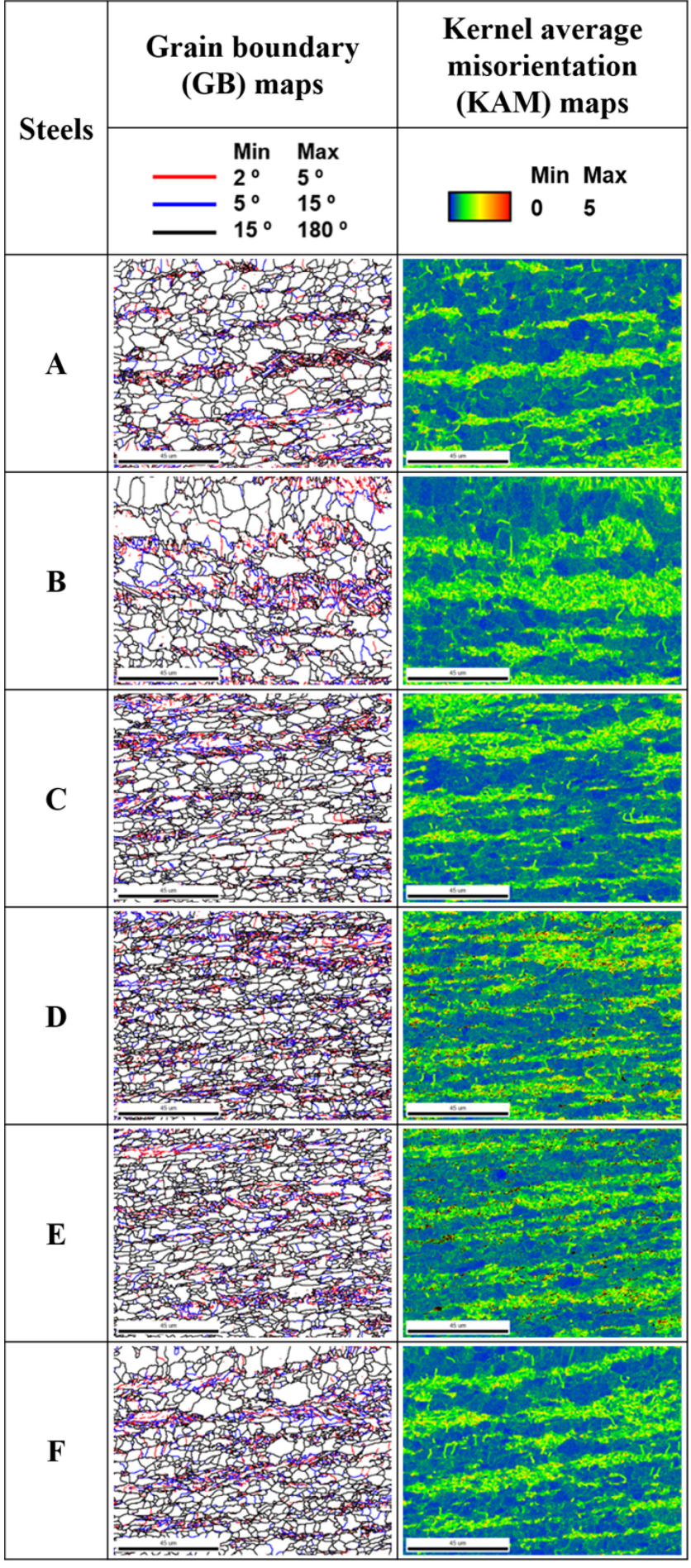

Fig. 2. EBSD grain boundary (GB) and kernel average misorientation (KAM) maps of the API X80 linepipe steels.

장 미세한 결정립 크기를 보였고, $\mathrm{C}$ 강은 $11.7 \mu \mathrm{m}$ 로 가 장 조대한 결정립 특성을 보였다. GOS 분석을 통한 미 세조직 분율 측정 결과를 보면(그림 3 및 표 1), 모든
강재에서 $\mathrm{PF}$ 분율이 $50 \%$ 이상으로 존재하였고, $\mathrm{B}$ 강이 $60.7 \%$ 로 가장 낮은 $\mathrm{PF}$ 분율을 나타냈으며, $\mathrm{A}, \mathrm{D}$ 및 $\mathrm{F}$ 강의 경우 $70 \%$ 이상의 높은 $\mathrm{PF}$ 분율을 보였다. 이는 $\mathrm{PF}$ 핵생성 관점에서 볼 때, $\mathrm{A}, \mathrm{D}$ 및 $\mathrm{F}$ 강들의 경우 상 대적으로 많은 $\mathrm{PF}$ 핵생성이 발생하여 많은 분율이 나타 난 것으로 생각할 수 있는데, 일반적으로 $\mathrm{PF}$ 핵생성 장 소는 구 오스테나이트 결정립계(prior austenite grain boundaries)로 알려져 있기 때문에 상대적으로 미세한 결 정립 특징을 보이는 $\mathrm{A}, \mathrm{D}$ 및 $\mathrm{F}$ 강들이 높은 $\mathrm{PF}$ 분율 을 나타낸 것으로 생각된다.

\section{2 인장 특성}

본 연구에서 제어 압연 및 가속 냉각 조건에 따라 미 세조직이 다른 6 종류의 API 라인파이프 강재를 제조한 후 상온 인장 실험을 실시한 공칭 응력-변형률 곡선을 그 림 4에 나타냈다. 제조 조건과 관계없이 모든 강재에서 불연속 항복 거동을 나타냈는데, 이는 본 연구에서 제조 된 강재의 경우 $\mathrm{PF}$ 가 주된 상으로 존재하기 때문에 많은 $\mathrm{PF}$ 내에 존재하는 고용 탄소 원자와 가동 전위와의 상호 관계에 의한 것으로 판단된다. 위의 응력-변형률 곡선으 로부터 얻은 인장 특성을 표 2에 정리하였는데, 본 연구 에서 제조된 $\mathrm{API}$ 라인파이프 강재의 경우 항복 강도 $551 \mathrm{MPa}$ 이상으로 모두 X80 급임이 확인되었다.

일반적으로 항복 강도의 경우 초기 미세조직적 인자에 의해 크게 영향을 받는데, 결정립 크기가 미세하거나, 경 한(hard) 미세조직의 분율이 높을수록 항복 강도가 크다. $\mathrm{D}$ 강의 경우 $606 \mathrm{MPa}$ 의 가장 높은 항복 강도 특성을 나타냈는데, $\mathrm{D}$ 강의 경우 다른 강에 비해 연한(soft) 미 세조직인 $\mathrm{PF}$ 분율이 다소 높지만, 가장 미세한 결정립으 로 인해 항복 강도가 가장 높은 것으로 판단된다. 이와는 반대로 $\mathrm{B}$ 및 $\mathrm{C}$ 강의 경우 낮은 $\mathrm{PF}$ 분율에도 불구하고 상대적으로 조대한 결정립 크기로 인해 항복 강도가 상 대적으로 낮았다. 인장 강도의 경우 $\mathrm{C}$ 강이 $681 \mathrm{MPa}$ 로 가장 높았다. 항복 강도를 인장 강도로 나눈 값으로 표현 되는 항복비의 경우 $\mathrm{D}$ 강이 0.92 로 가장 높았고, $\mathrm{C}$ 강 이 0.85 로 가장 낮았다. 한편 Hollomon 식에 기반하여 인장 응력-변형률 곡선으로부터 측정한 가공경화지수의 경우 $\mathrm{A}$ 와 $\mathrm{F}$ 강이 0.140 이상으로 상대적으로 높았으며, $\mathrm{E}$ 강이 0.128 로 가장 낮은 가공경화지수를 보였다. 항복 비와 더불어 고변형능 특성에 요구되는 균일 연신율의 경 우 모든 강재에서 $10 \%$ 이상의 높은 값을 보였으며, 특 히 $\mathrm{A}, \mathrm{D}$ 및 $\mathrm{F}$ 강들의 경우 $12 \%$ 이상의 우수한 고변형 능 특성을 나타냈다. 

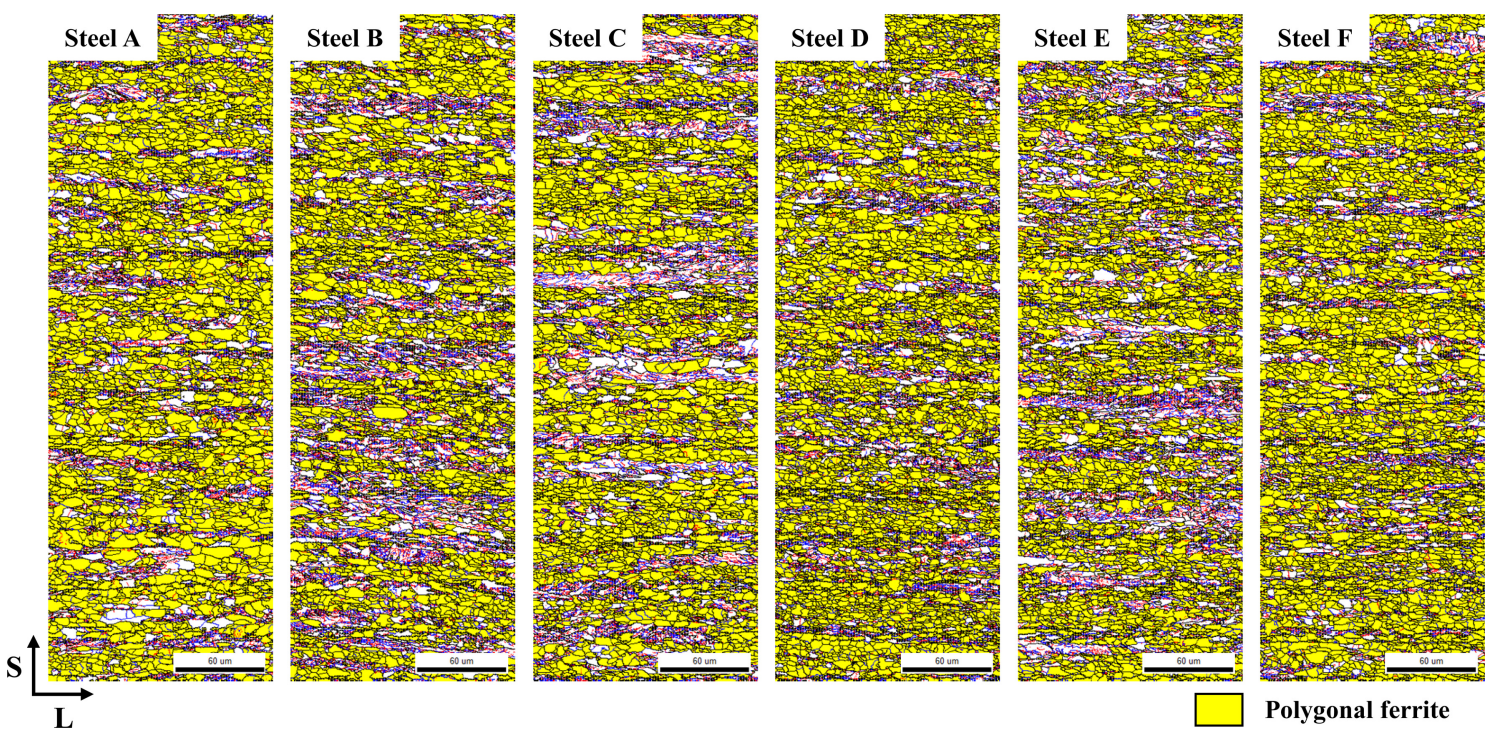

Fig. 3. EBSD grain boundary maps according to GOS condition for the API X80 linepipe steels. In EBSD grain boundary maps, the angle ranges of red, blue, and black lines are $2^{\circ}$ to $5^{\circ}, 5^{\circ}$ to $15^{\circ}$, and $15^{\circ}$ to $180^{\circ}$, respectively.

Table 1. Microstructure fraction and grain size of the API X80 linepipe steels investigated in this study.

\begin{tabular}{|c|c|c|c|}
\hline \multirow[b]{2}{*}{ Steels } & \multicolumn{2}{|c|}{ Microstructure fraction (\%) } & \multirow{2}{*}{$\begin{array}{l}\text { Grain size* } \\
\quad(\mu \mathrm{m})\end{array}$} \\
\hline & $\begin{array}{c}\text { Polygonal } \\
\text { ferrite }\end{array}$ & $\begin{array}{c}\text { Bainitic } \\
\text { microstructure }\end{array}$ & \\
\hline A & 74.1 & 25.9 & 8.5 \\
\hline B & 60.7 & 39.3 & 10.4 \\
\hline $\mathrm{C}$ & 67.7 & 32.3 & 11.7 \\
\hline $\mathrm{D}$ & 76.1 & 23.9 & 6.7 \\
\hline $\mathrm{E}$ & 63.9 & 36.1 & 9.4 \\
\hline $\mathrm{F}$ & 77.2 & 22.8 & 7.5 \\
\hline
\end{tabular}

*The grain size represents the size of crystallographic domains having high-angle grain boundary of $15^{\circ}$ or more obtained from EBSD analysis.

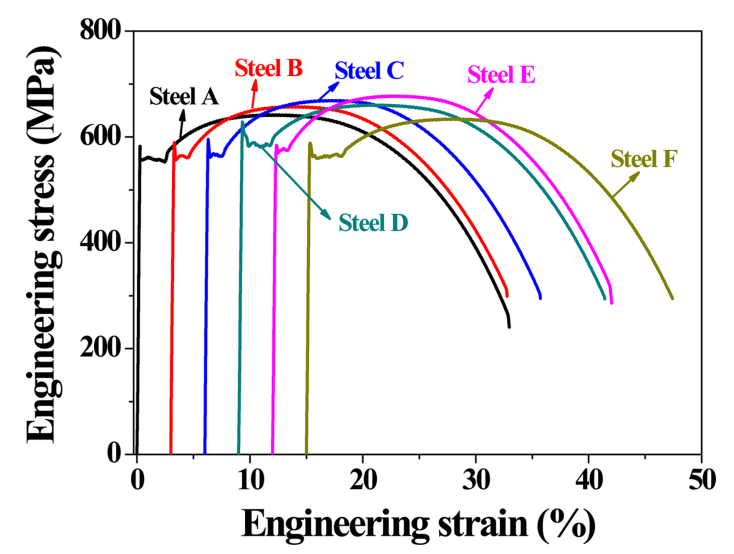

Fig. 4. Engineering stress-strain curves of the API X80 linepipe steels.

\section{4. 결과 고찰}

\section{1 미세조직적 인자와 항복비의 상관관계}

$\mathrm{API}$ 라인파이프강 강재의 기계적 특성은 미세조직 구성 에 크게 의존하기 때문에 우수한 변형능 특성을 갖는 API 라인파이프 강재를 개발하기 위해서는 다양한 미세조직적 인자와 기계적 특성의 상관관계를 이해하는 것이 매우 중 요하다. 최근 여러 연구자들로부터 API 라인파이프 강재에 대한 미세조직의 영향을 설명하는 연구가 보고되고 있는 데, Yasuda 등[18]의 연구 결과에 따르면 베이나이트-페라 이트의 2상 조직을 갖는 라인파이프 강재에서 베이나이트 가 $20 \%$ 에서 $40 \%$ 사이의 분율을 가질 때 가장 낮은 항 복비를 가지는 결과를 보였다. Sung 등[19]은 동일 화학 조성을 갖는 시편에 대하여 냉각 종료 온도를 달리하여 미 세조직 분율을 변화시켜 기계적 물성에 미치는 영향을 평 가하였다. 그들의 결과에 의하면, 고강도 베이나이트 강의 인장 강도와 연신율은 $\mathrm{BF}$ 와 마르텐사이트-오스테나이트 (martensite-austenite, MA)의 영향을 받으며 MA가 증가함 에 따라 항복비는 직선적으로 감소하였다. 이는 변형 시 페라이트와 $\mathrm{MA}$ 사이의 결정립계 주변에서 많은 양의 전 위가 생성되는데, 이 전위들은 이동이 쉬운 가동 전위로서 존재하기 때문에 항복비가 $\mathrm{MA}$ 와 같은 경한 상에 의한 전 위 밀도에 큰 영향을 받는다고 보고하였다. 한편 Igari 등 [20]의 연구에 의하면 균일 연신율을 증가시키는 효과적인 방법으로는 페라이트 또는 MA 같은 경한 상을 도입시키 
(a)

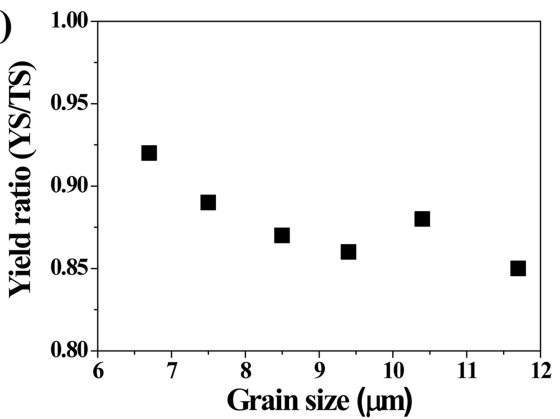

(c)

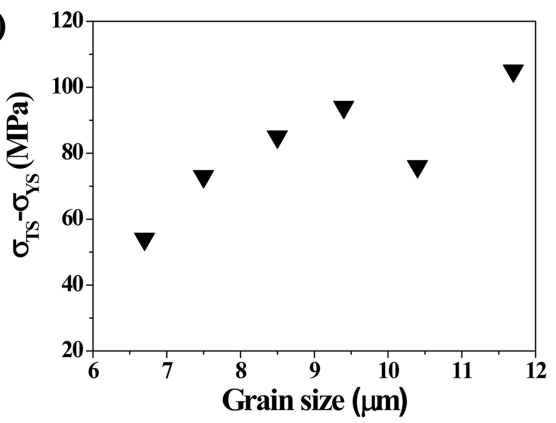

(e)

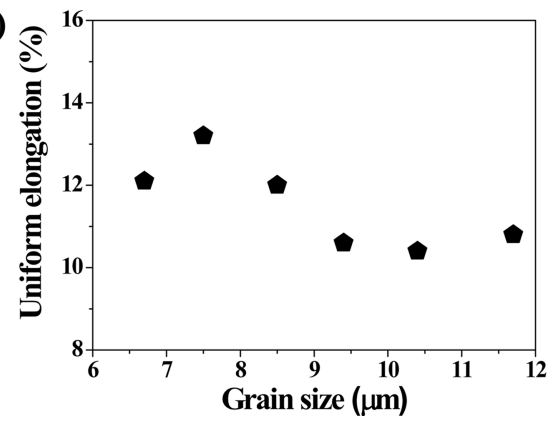

(b)

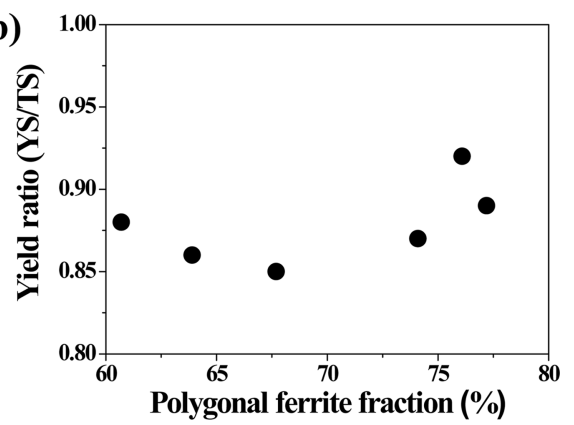

(d)

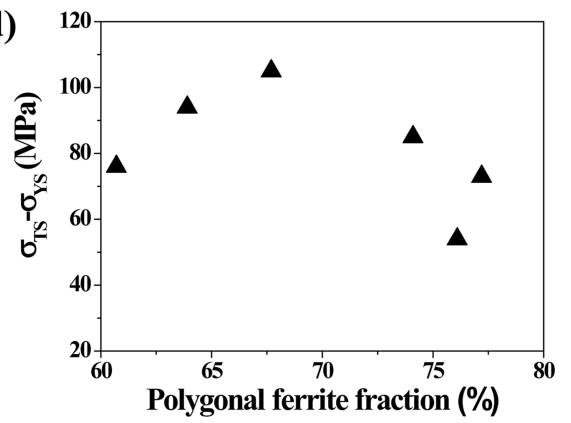

(f)

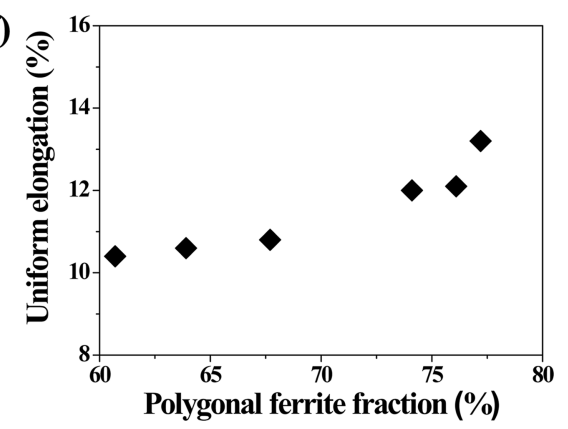

Fig. 5. Effect of the (a, c, e) grain size, and the (b, d, f) polygonal ferrite fraction on the yield ratio, difference in tensile and yield strengths $\left(\sigma_{\mathrm{TS}}-\sigma_{\mathrm{YS}}\right)$, and uniform elongation of the API X80 linepipe steels.

는 것이 있다. 이는 $\mathrm{MA}$ 변태 시, 높은 변형능에 기여하 는 전위들이 생성되기 때문이라고 보고하였다. 결과적으로 Igari 등은 높은 강도 및 균일 연신율을 가지는 강재에 적 합한 미세조직으로 MA가 함유된 페라이트-베이나이트의 2상 조직을 제시하였다.

본 연구에서는 다양한 제어 압연 및 가속 냉각 조건에 의 해 제조된 강재의 대하여 상온 인장 특성을 평가한 후 미세 조직적 인자의 영향에 대해 분석한 결과는 다음과 같다. 그 림 5(a)와 (b)에 결정립 크기 및 $\mathrm{PF}$ 분율에 따른 항복비 변 화를 나타냈다. 항복비는 항복 강도를 인장 강도로 나눈 값 으로 항복비에 미치는 미세조직적 인자에 대해 고찰하기 위 해서는 항복 강도와 인장 강도를 나누어 각 특성에 미치는 미세조직의 영향에 대해 고찰할 필요가 있다. 본 연구에서 제조된 강재의 경우 그림 5(a)에 나타낸 것과 같이 결정립
크기가 작아질수록 항복비가 커지는 경향을 나타냈지만, 미 세조직 분율에 따른 큰 변화는 보이지 않았다(그림 $5(\mathrm{~b})$ ). 또한 결정립 크기 및 $\mathrm{PF}$ 분율에 따른 응력 변화량(인장 강 도 - 항복 강도)을 보면(그림 5(c), (d) 및 표 2), 응력 변 화량은 $\mathrm{PF}$ 분율에 큰 영향을 받지 않지만, 결정립 크기가 작을수록 응력 변화량이 작아짐을 확인할 수 있는데, 이는 상대적으로 조대한 결정립 크기를 갖는 강재의 경우 항복 이후 높은 가공경화가 일어났다고 생각할 수 있다. 일반적 으로 결정립 크기가 미세해질수록 아래의 잘 알려진 홀 페 치(Hall-Petch) 관계식에 의해 결정립 미세화 강화에 의해 항복 강도가 크게 증가한다고 보고되고 있다 [41].

$$
\sigma_{0}=\sigma_{i}+k D^{-1 / 2}
$$

여기서 $\sigma_{0}$ 는 항복 강도, $\sigma_{i}$ 는 전위 운동에 대한 결정 격 
Table 2. Tensile properties of the API X80 linepipe steels investigated in this study.

\begin{tabular}{|c|c|c|c|c|c|c|c|}
\hline Steels & $\begin{array}{l}\text { Yield strength } \\
\quad(\mathrm{MPa})\end{array}$ & $\begin{array}{l}\text { Tensile strength } \\
\text { (MPa) }\end{array}$ & Yield ratio & $\begin{array}{c}\sigma_{\mathrm{TS}}-\sigma_{\mathrm{YS}} \\
(\mathrm{MPa})\end{array}$ & $\begin{array}{l}\text { Work hardening } \\
\text { exponent** }\end{array}$ & $\begin{array}{c}\text { Uniform } \\
\text { elongation }(\%)\end{array}$ & $\begin{array}{c}\text { Total elongation } \\
(\%)\end{array}$ \\
\hline A & 557 & 642 & 0.87 & 85 & 0.142 & 12.0 & 32.2 \\
\hline $\mathrm{B}$ & 580 & 656 & 0.88 & 76 & 0.130 & 10.4 & 29.4 \\
\hline $\mathrm{C}$ & 576 & 681 & 0.85 & 105 & 0.135 & 10.8 & 30.3 \\
\hline $\mathrm{D}$ & 606 & 660 & 0.92 & 54 & 0.139 & 12.1 & 31.8 \\
\hline E & 583 & 677 & 0.86 & 94 & 0.128 & 10.6 & 29.5 \\
\hline $\mathrm{F}$ & 563 & 636 & 0.89 & 73 & 0.145 & 13.2 & 33.7 \\
\hline
\end{tabular}

* $\sigma_{\mathrm{TS}}-\sigma_{\mathrm{YS}}$ is difference between tensile strength and yield strength

** The work hardening exponent was measured from tensile stress-strain curves based on Hollomon equation [41].

자의 저항을 나타내는 마찰 응력, $k$ 는 결정립계의 상대적 강화에 기여도를 측정하는 저지 계수, $D$ 는 결정립 크기를 나타낸다. 하지만 결정립 미세화에 의해 인장 강도 역시 증가한다고 알려져 있는데, 실제로 결정립 미세화에 의해 항복 강도가 인장 강도보다 더 크게 증가하기 때문에 항복 비를 증가시킨다. 이를 미세조직적으로 생각해보면, 일반적 으로 강도는 전위의 움직임에 의해 설명될 수 있으며 전위 의 슬립이 억제되면 강도가 증가한다. 따라서 결정립이 미 세화되었을 경우 증가된 결정립계에 의해 전위의 슬립이 억제되어 항복 강도가 증가한다. 하지만 항복 이후 전위 밀도가 증가하고, 전위들이 결정립계, 석출물들의 장애물에 집적(pile up)되어 역 응력(back stress)이 발생하는데, 이 역 응력이 가공경화의 주된 기구로 보고된다 [41]. 또한 집 적되는 전위의 수는 결정립 크기에 영향을 받는데, 전위 원이 직경 $\mathrm{D}$ 인 결정립이 중심에 놓여있을 때 집적된 전위 의 수는 다음과 같다 [41].

$$
n=\frac{k \pi \tau_{s} D}{4 G b}
$$

여기서 $n$ 은 집적된 전위의 수, $k$ 는 1 에 가까운 상수, $\tau_{s}$ 는 슬립면에서의 평균 분해 전단 응력, $D$ 는 결정립 크기, $G$ 는 강성률, $b$ 는 버거스(Burgers) 벡터이다. 위 식에서 알 수 있듯이 집적된 전위의 수는 결정립 크기에 비례한다고 생각할 수 있다. 즉 결정립 미세화에 의해 집적된 전위의 수가 감소되고 이로 인해 역 응력이 상대적으로 작아 가공 경화가 적게 일어난다고 판단할 수 있다. 결과적으로 결정 립이 미세해질수록 항복비가 증가하는 결과는, 탄성 변형 영역(elastic deformation region)에서의 결정립 미세화에 의한 큰 항복 강도 증가와 동시에 소성 변형 구간(plastic deformation region)에서의 상대적으로 적은 가공경화에 의 한 것으로 이해될 수 있다.

\section{2 미세조직적 인자와 균일 연신율의 상관관계}

한편 최근 항복비와 더불어 고변형능 특성으로 요구되는 균일 연신율 또한 미세조직 인자에 의존한다. 균일 연신율 의 경우 응력(stress) 개념인 항복비와는 달리 변형률 (strain) 측면에서 생각할 수 있다. 균일 연신율은 항복 이 후 네킹이 발생하기 전까지 시편이 균일하게 연신되는 구 간으로, 시편 전체에서 전위의 슬립이 폭넓게 이루어지는 경우 높은 균일 연신율 특성을 나타낸다고 생각할 수 있 다. 전위의 슬립은 결정립계, 석출물, 고용 원자 등과 같은 장애물에 의해 억제될 수 있고 전위들 간의 상호작용에 의 해서도 억제가 가능한 것으로 알려져 있다 [41]. 따라서 높은 균일 연신율을 얻기 위해서는 결정립 내에서 원활한 전위의 슬립 분위기를 형성하는 것이 매우 중요하다고 할 수 있다.

결정립 크기 및 $\mathrm{PF}$ 분율에 따른 균일 연신율 변화를 나 타낸 그림 5(e) 및 (f)를 보면, 결정립 크기가 미세해질수 록, $\mathrm{PF}$ 분율이 증가할수록 균일 연신율이 증가하였다. 본 연구에서 제조된 강재들의 경우 화학 조성이 동일하지만, 제조 공정에 따라 다른 미세조직 분율을 갖기 때문에, 앞 절에서 설명한 바와 같이 결정립 미세화에 의한 핵 생성처 증가가 미세조직 분율에 영향을 미친다. 따라서 균일 연신 율에 미치는 결정립 크기 및 $\mathrm{PF}$ 분율의 영향은 동시에 관 련 지어 생각할 수 있다. 본 연구에서 결정립이 미세한 강 재들 $(\mathrm{A}, \mathrm{D}$ 및 $\mathrm{F}$ 강)의 경우 상대적으로 많은 $\mathrm{PF}$ 분율을 나타낸다. 또한 제어 압연 및 가속 냉각에 의해 제조되는 $\mathrm{API}$ 라인파이프 강재의 경우 $\mathrm{PF}$ 이외에 $\mathrm{AF}, \mathrm{GB}$ 및 $\mathrm{BF}$ 와 같은 복잡한 저온 변태조직들이 존재하는데, 이러한 조 직들의 경우 내부에 경한 2 차상 및 높은 전위 밀도로 인 해 $\mathrm{PF}$ 상과 비교하여 낮은 전위의 슬립 거동을 나타낸다 $[35,40]$. 즉 결정립이 미세한 강재들은 전위의 슬립이 상대 적으로 원활히 일어나는 $\mathrm{PF}$ 분율이 많아 소성 불안정성을 야기시키는 전위 집적에 의한 네킹을 감소시키기 때문에 
(a)

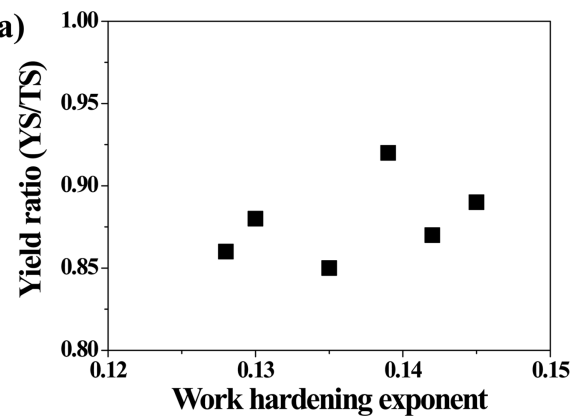

(b)

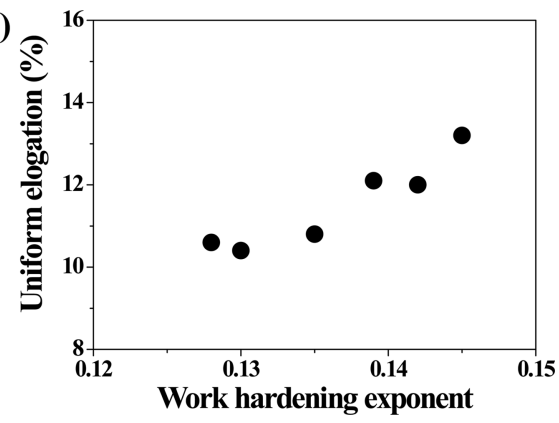

Fig. 6. Correlation of work hardening exponent with the (a) yield ratio and (b) uniform elongation of the API X80 linepipe steels.

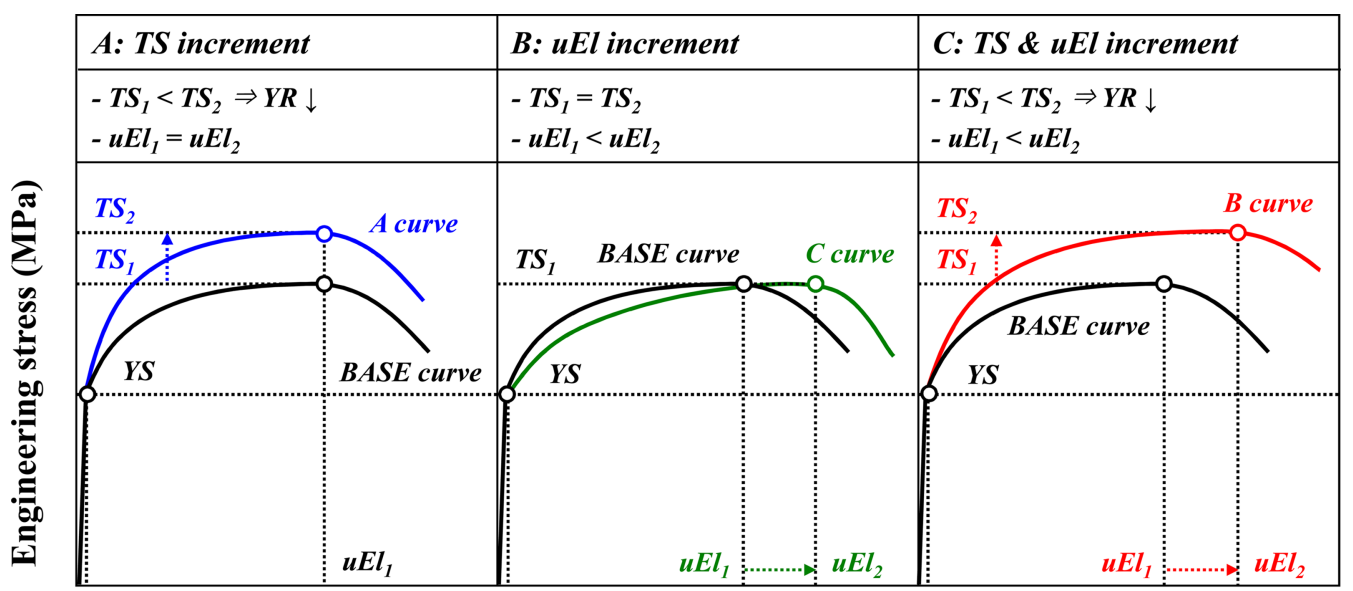

Engineering strain (\%)

Fig. 7. Schematic diagram of engineering stress-strain curves to explain the correlation between yield ratio (YR), uniform elongation (uEl), and work hardening exponent for the steels with different tensile strength (TS) and uniform elongation at the same yield strength (YS).

높은 균일 연신율 특성을 나타낸다고 볼 수 있다. 따라서 저항복비 및 높은 균일 연신율의 고변형능 특성을 동시에 갖는 API 라인파이프 강재를 개발하기 위해서는 결정립 크기를 상대적으로 조대하게 제조하고 조대한 결정립으로 인한 부족한 강도 특성은 고용 강화 및 석출 강화와 같은 다른 강화 기구에 의해 만족시켜야 함을 알 수 있다.

\section{3 항복비, 균일 연신율, 가공경화지수의 상관관계}

다양한 미세조직을 갖는 API 라인파이프 강재의 항복비 및 균일 연신율 특성은 가공경화지수와 밀접한 관계가 있 다고 보고되고 있는데, $\mathrm{Ji}$ 등[21]은 고강도 라인파이프 강 재에서 가공경화지수는 균일 연신율 및 항복비에 영향을 주며 가공경화지수가 증가할수록 항복비가 낮아진다고 보 고하고 있다. Schwinn 등[22]은 X100 급의 라인파이프 강재에 대하여 고변형률 특성을 평가한 결과, 항복비가 낮 아질수록 높은 균일 연신율 특성을 갖는 반비례 관계가 성 립한다고 설명하고 있다. 그러나 본 연구에서 제조된 API
라인파이프 강재의 경우, 가공경화지수가 증가할수록 항복 비 및 균일 연신율이 증가하는 경향을 보였다(그림 6). 가 공경화지수는 외부 응력에 의해 가공된 재료의 강성이 증 가하는 정도를 나타내는 지수로, 이는 항복 이후 균일 변 형 영역에서 응력-변형률 곡선의 기울기로 표현된다. 즉, 가 공경화지수는 응력과 변형률이 동시에 영향을 미치는 값으 로, 미세조직적 인자의 영향을 보다 체계적으로 분석하기 위해서는 항복비와 균일 연신율을 응력 및 변형률 관점에 서 분리하여 고찰할 필요가 있다.

응력과 변형률 변화에 따라 가공경화지수와 항복비 및 균일 연신율 간의 상관관계를 그림 7에 도식적으로 나타 냈다. 먼저 A 형태처럼 균일 연신율 변화 없이 인장 강도 만 증가할 경우 가공경화지수가 증가할수록 항복비가 감소 하기 때문에 가공경화지수와 균일 연신율은 상관관계가 없 다고 생각될 수 있다. 다음으로 $\mathrm{B}$ 형태처럼 강도 변화 없 이 균일 연신율이 증가한 경우, $\mathrm{A}$ 형태와는 반대로 가공 경화지수에 따라 균일 연신율은 변하지만, 항복비에 영향 


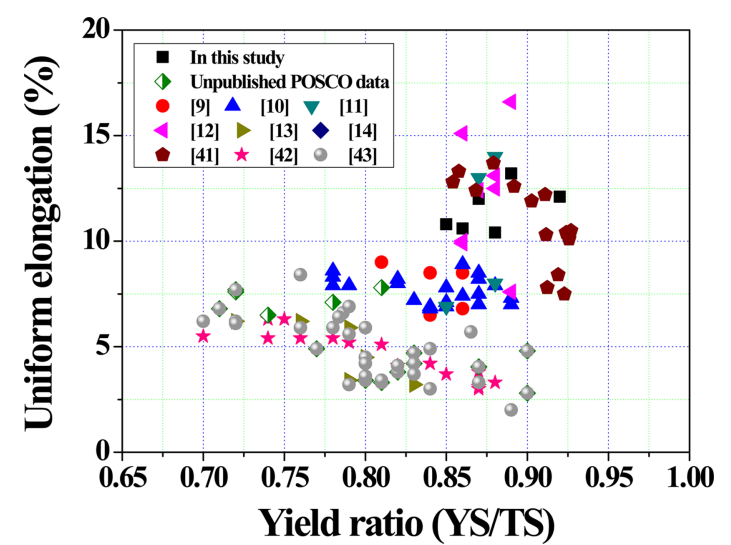

Fig. 8. Yield ratios and uniform elongations of the API X80 linepipe steels investigated in this study and previously reported API linepipe steels [9-14,42-44].

을 주지 않는 것으로 생각할 수 있다. 세번째로 $\mathrm{C}$ 형태와 같이 인장 강도와 균일 연신율이 모두 변화하는 경우 곡선 의 기울기 형태에 따라 항복비와 균일 연신율에 미치는 가 공경화지수의 영향이 다르게 나타난다. 결과적으로 항복 비, 균일 연신율 및 가공경화지수에 영향을 미치는 미세조 직적 인자는 서로 다르며, 가공경화지수는 응력과 변형률 변화에 동시에 의존하는 특성 값으로 항복비, 균일 연신율 및 가공경화지수 사이에는 일반적인 상관관계가 존재하지 않음을 알 수 있다. 현재까지 보고된 API 라인파이프 강 재들과 본 연구에서 제조된 강재들에 대하여 항복비와 균 일 연신율의 상관관계를 비교한 그림 8 그래프를 보면[9$14,42-44]$, 항복비와 균일 연신율 간에는 비례관계가 성립 하지 않음을 확인할 수 있다.

\section{5. 결 론}

본 연구에서는 $\mathrm{TMCP}$ 조건에 따라 다양한 미세조직을 갖 는 API 라인파이프 강재에 대하여 미세조직적 인자를 정 량적으로 측정하고, 인장 시험을 실시한 후 미세조직과 인 장 특성 간의 상관관계를 고찰하여 다음과 같은 결론을 얻 었다.

(1) 항복 강도는 공정 변수에 따른 미세조직 분율과 결 정립 크기에 동시에 의존하는데, 결정립 크기가 미세하거 나 경한 미세조직의 분율이 높을수록 항복 강도가 일반적 으로 크다. 본 연구에서 제조된 $\mathrm{D}$ 강은 다른 강에 비해 연한 미세조직인 $\mathrm{PF}$ 분율이 다소 높지만, 가장 미세한 결 정립으로 인해 항복 강도가 가장 높았다.

(2) 항복비에 미치는 미세조직의 영향에 대해 분석한 결
과 결정립 크기가 작아질수록 항복비가 대체로 증가하였다. 이는 결정립 미세화에 의한 항복 강도 증가와 전위 집적에 의한 가공경화 감소로 설명될 수 있었다.

(3) 항복비와 함께 고변형능 특성으로 요구되는 균일 연 신율의 경우 $\mathrm{PF}$ 분율이 높을수록 균일 연신율이 증가하였 는데, 이는 전위 슬립이 용이한 $\mathrm{PF}$ 분율 증가가 소성 불 안정성을 야기시키는 전위 집적에 의한 네킹을 감소시키기 때문으로 생각된다.

(4) 결과적으로 항복비, 균일 연신율 및 가공경화지수에 미치는 미세조직적 인자는 서로 다르며, 가공경화지수는 응력과 변형률 변화에 동시에 의존하는 특성 값으로 항 복비, 균일 연신율 및 가공경화지수 사이에는 일반적인 상 관관계가 존재하지 않았다.

\section{감사의 글}

이 연구는 서울과학기술대학교 교내연구비의 지원으로 수행되었습니다.

\section{REFERENCES}

1. M. K. Gräf, H. G. Hillenbrand, C. J. Heckmann, and K. A. Niederhoff, Proceeding 13th International Offshore and Polar Engineering Conference, 97, ISOPE, Hawaii, USA (2003).

2. T. Schambron, A. Dehghan-Manshadi, L. Chen, T. Gooch, C. Killmore, and E. Pereloma, Met. Mater. Int. 23, 778 (2017).

3. C. W. Choi, H. J. Koh, and S. Lee, Metall. Mater. Trans. 31A, 2669 (2000).

4. J. Miao and Q. Wang, Met. Mater. Int. 22, 797 (2017).

5. X. Deng, T. Fu, Z. Wang, G. Liu, G. Wang, and R. D. K. Misra, Met. Mater. Int. 23, 175 (2017).

6. X. K. Zhu and B. N. Leis, Int. J. Pres.Ves. Pip. 83, 663, (2006).

7. B. Liu, X. J. Liu, and H. Zhang, J. Loss Prev. Process Ind. 22, 884 (2009).

8. A. B. Dorey, D. W. Murray, J. J. R. Cheng, G. Y. Grondin and Z. J. Zhou, Proceedings of the 27th International Conference on OMAE, ASME Paper No OMAE99, PIPE5022, ASME, Newfoundland, Canada (1999).

9. Y. Shinohara, T. Hara, E. Tsuru, H. Asahi, N. Doi, N. Ayukawa, and M. Murata, Proceedings of 17th International Offshore and Polar Engineering Conference, 2949, ISOPE, Lisbon, Portugal (2007). 
10. T. Hara, Y. Shinohara, Y. Terada, H. Asahi, and N. Doi, Proceeding 19th International Offshore and Polar Engineering Conference, 73, ISOPE, Osaka, Japan (2009).

11. H. K. Sung, D. H. Lee, S. Lee, H. S. Kim, Y. Ro, C. S. Lee, B. Hwang, and S. Y. Shin, Metall. Mater. Trans. A 47A, 2726 (2016).

12. H. K. Sung, D. H. Lee, S. Y. Shin, S. Lee, J. Y. Yoo, and B. Hwang, Mater. Sci. Eng. A 624, 14 (2015).

13. H. K. Sung, S. Y. Shin, B. Hwang, C. G. Lee, N. J. Kim, and S. Lee, Metall. Mater. Trans. A 42A, 1827 (2011).

14. J. H. Bae, Y. J. Ro, S. H. Chon, H. K. Sung, S. Lee, and C. S. Lee, Proceeding 25th International Offshore and Polar Engineering Conference, 657, ISOPE, Hawaii, USA (2015).

15. Y. Shinohara, T. Hara, E. Tsuru, H. Asahi, and N. Doi, Proceedings of 24th International Conference on OMAE, ASME Paper No OMAE2005-67055, ASME, Halkidiki, Greece (2005).

16. C. Timms, D. DeGeer, and M. McLamb, Proceedings of 24th International Conference on OMAE, ASME Paper No OMAE2005-67401, ASME, Halkidiki, Greece (2005).

17. S. Adeeb, J. Zhou, and D. Horsley, Proceedings of International Pipeline Conference, 25, ASME, Alberta, Canada (2006).

18. K. Yasuda, H. Sueyoshi, N. Ishikawa, T. Morikawa, and K. Higashida, Proceeding 25th International Offshore and Polar Engineering Conference, 639, ISOPE, Hawaii, USA (2015).

19. H. K. Sung, S. Lee, and S. Y. Shin, Metall. Mater. Trans. A 45A, 2004 (2014).

20. H. Igari, H. Nakamura, and S. Okaguchi, Proceeding 21th International Offshore and Polar Engineering Conference, 569, ISOPE, Hawaii, USA (2011).

21. L. Ji, X. Li, H. Chen, C. Y. Huo, S. Gong, and X. Zhao, Proceeding 18th International Offshore and Polar Engineering Conference, 3007, ISOPE, Lisbon, Portugal (2007).

22. V. Schwinn, P. Fluess, A. Liessem, and J. Schroeder, Proceeding 18th International Offshore and Polar Engineering Conference, 27, ISOPE, Vancouver, Canada (2008).

23. D. W. Murray, Eng. Struct. 19, 360 (1997).

24. F. C. Bardi and S. Kyriakides, Int. J. Mech. Sci. 48, 830
(2006).

25. F. C. Bardi, S. Kyriakides, and H. D. Yuri, Int. J. Mech. Sci. 48, 842 (2006).

26. N. Ishikawa, S. Endo, and J. Kondo, JFE Technical Report 7, 20 (2006).

27. T. Arakawa, K. Nishimura, K. Yano, and N. Suzuki, JFE Technical Report 18, 23 (2013).

28. H. Zhang, B. E. Schuster, Q. Wei, and K. T. Ramesh, Scripta Mater. 54, 181 (2006).

29. A. C. Palmer and R. A. King, Subsea Pipeline Engineering, 23, PennWell Books, Oklahoma (2004).

30. Q. Bai and Y. Bai, Subsea Pipeline Design, Analysis, and Installation, 67, Gulf Professional Publishing, Oxford, (2014).

31. Z. Wang, Z. Huachen, H. Liu, and Y. Bu, Ocean Eng.104, 249 (2015).

32. L. Wang, R. Shi, F. Yuan, Z. Guo, and L. Yu, Appl. Ocean Res. 33, 130 (2011).

33. T. Z. Yao, Adv. Mat. Res. 317, 154 (2011).

34. API Specification 5L, Specification for Line Pipe, 43th Edition, American Petroleum Institute, USA (2004).

35. T. Araki, I. Kozasu, H. Tankechi, K. Shibata, M. Enomoto, and H. Tamehiro, Atlas for Bainitic microstructures, 1, ISIJ, Tokyo, Japan (1992).

36. G. Krauss and S.W. Thompson, ISIJ 35, 937 (1995).

37. S. W. Thompson, D. J. Colvin, and G. Krauss, Metall. Trans. A 21A, 1493 (1990).

38. B. L. Bramfitt and J. G. Speer, Metall. Trans. A 21A, 817 (1990).

39. T. Araki, M. Enomoto, and K. Shibata, Mate. Trans. JIM, 32, 729 (1991).

40. S. I. Lee, T. W. Hong, and B. Hwang, Korean J. Mater. Res. 27, 636 (2017).

41. G. E. Dieter, Mechanical Metallurgy, McGraw-Hill, London (1988).

42. H. Asahi, Y. Shinohara, and T. Hara, U.S. Patent 8070887B2 (2011).

43. H. Asahi, T. Hara, Y. Terada, M. Sugiyama, N. R. Bangaru, J. Y. Koo, H. W. Jin, A. Ozekcin, and D. Fairchild, U.S. Patent 2007/0193666A1 (2007).

44. B. Hwang, C. G. Lee, S. Lee, and C. Lee, Trends in Metals and Materials Engineering 22, 4 (2009). 